\title{
Digital Divide: How can digital libraries bridge the gap?
}

\author{
Gobinda G. Chowdhury \\ Graduate School of Informatics \\ Department of Computer and Information Sciences \\ University of Strathclyde \\ Glasgow, UK \\ e-mail: gobinda@dis.strath.ac.uk
}

\begin{abstract}
Recent developments in Information and Communication Technologies (ICT) have, while making our life easier, created a social divide that is known as the digital divide. Statistics show that there are significant disparities among the population in the developed and developing world in terms of the accessibility to, and use of, ICT. Research and development in digital libraries do not only require sophisticated ICT, they also call for huge investment in terms of money and intellectual resources. Developing countries are lagging behind in digital library research and development due to the digital divide, as well as due to the lack of appropriate resources required for research and development in digital libraries. As a result users in the developing world are being deprived of digital library services. This paper argues that some recent global digital library developments can be used by users in the developing countries, and thus digital libraries can play a significant role in bridging the gap. These developments include subject gateways, digital reference services, free access to e-journals and ebooks in many areas, and e-print archives and free digital libraries. The paper ends with an action plan that may be used by library and information professionals in the developing countries, as well as developed countries, to exploit the benefits of these digital information resources and services, and thus to some extent can bridge the gap of digital divide.
\end{abstract}

\section{Introduction}

While the information and communication technologies (ICT) in general, and the Internet and the world wide web in particular, have made life easier by facilitating easy communication with virtually everyone, and easy access to information located virtually anywhere in the world, they have also widened the gap between the rich and the poor, the 'have' and the 'have nots'. In other words, new technologies, while improving our life in many ways have created what is called the 'digital divide'. The digital divide has become a popular phrase to describe the perceived disadvantages of those who are either unable, or do not choose, to use the appropriate ICT in their day-to-day activities, decision making, learning and pleasure [1]. It is caused by a number of divides, such as the infrastructure, hardware, running costs, manpower, and information and digital literacy.

Digital libraries make use of ICT and the web to provide access to the local and remote digital information sources and services. Therefore, accessibility to the basic ICT and the Internet is a prerequisite to the development and use of digital libraries. There are many other factors too. The two most important issues are (1) the cost of building and maintaining sustainable digital library systems and services, and (2) achieving the required information literacy standards so as to exploit the full benefits of digital libraries. This paper discusses the problems facing the developing countries in these two areas the consequence of which is the widening of the gaps between the developed and the developing countries in terms of accessibility to digital information sources and services. This paper argues that some recent global digital library developments can be used by users in the developing countries, and thus digital libraries can play a significant role in bridging the gap. Finally the paper shows how digital library services can be set up with minimum initial investments in the developing counties in order to make some of the global digital library sources and services available to the users.

\section{Digital Divide: Some Facts and Figures}

The Digital Divide Basics Fact Sheet [2] shows that there are an estimated 429 million people (only $6 \%$ of the world's entire population) online globally, with the following distribution:

- $41 \%$ of the global online population is in the United States and Canada 
- $27 \%$ of the online population lives in Europe, the Middle East and Africa

- $20 \%$ of the online population logs on from Asia Pacific

- Only $4 \%$ of the world's online population are in South America.

Digital divide, however, is not necessarily a developing country phenomenon. In Britain, it is estimated that more than 60 percent of the richest ten percent of the population have household access to the Internet, whereas among the poorest $10 \%$, only $6 \%$ have household access to the Internet [3]. In the Fall of 2000, the US Department of Commerce found that only $41.5 \%$ of all US homes had Internet access [4].

However, disparities in the least developed countries are mind-boggling; most people don't even have a phone, let alone an online connection, either at work or home. According to BBC [5], 'more than $80 \%$ of people in the world have never even heard a dial tone, let alone surfed the Web'. United Nations Secretary General Kofi Annan recently said that the Internet is used only by five percent of the world's population [6].

\section{Money Spent in Digital Library Research and Development}

Huge amount of money has been spent in digital library research and development. In the United States, over US\$ 24 million was awarded in 1994 as part of the first Digital Library Initiative (DLI-1), and over US\$55 million has been allocated so far in the second phase which will be much more if the funding for the recent joint international projects is counted. There have been several other research projects on digital libraries outside the DLI funding in the United States (for details see [7]). Research on digital libraries in the United Kingdom has largely been funded by the Electronic Libraries (eLib) Programme. The three phases of eLib had a costing in excess of $£ 20$ million [8].

These figures are just the tip of the iceberg as far as the total amount of money spent for digital library research and development is concerned. A large number of digital library projects have been funded by libraries, universities and other institutions the total cost of which is difficult to calculate. Harvard University has a budget of $\$ 12$ million over a period of five years in the Library Digital Initiative [9]. University of Central England, UK has a capital allocation of over $£ 1$ million for a period of three years for the digital library systems and services [10]. This are just some figures to give an idea of the amount spent at the institutional level. A large number of similar digital library projects have been undertaken in Europe and in other parts of the world.

Developing countries, especially the least developed countries, that struggle to meet the basic human needs, cannot afford to spend such huge amount of money required for research and development of digital libraries. In addition, there are many other problems that stand in the way of digital library development in the developing countries.

\section{Problems of Digital Library Development and Use in Developing Countries}

Library development has not been a priority of governments in the developing countries. Governments struggle to meet the basic human needs like food, water, health, electricity, sanitation, transportation, etc. Consequently, libraries have long been suffering from financial and other crises such as lack of the appropriate technology, trained manpower, etc. Libraries have also been affected by a number of social problems, the primary ones being the poor literacy rates. While governments are struggling to improve the levels of basic literacy, proper use of library and information services call for another level of literacy - the information literacy that is absolutely necessary for people to become good information users. Due to the lack of suitable technologies and trained manpower, and above all due to the lack of financial resources, most libraries in the developing countries do not even have fully developed and up to date OPACs, let alone full-fledged automated library management systems, and digital libraries. Hence compared with the developed world scenario, libraries in the developing countries are already left behind by at least one generation. Digital divide, and lack of resources for digital library research and development, may increase the gap far more significantly between library and information services in developed and developing countries. 
The following is a short list of problems or issues that stand in the way of digital library research and development in the developing countries:

- Shrinking library budget that forces the library management to struggle to maintain a minimum standard of services leaving no room for new ventures and developments

- Lack of financial support specifically for digital library research and development

- Absence of fully developed and up to date OPACs, and little access to online information resources - online databases, e-journals, etc.

- $\quad$ Poor ICT - computers and networks

- Poor facilities for access to ICT, especially the Internet

- Stringent government and institutional policies on Internet access

- Lack of trained manpower

- Poor information literacy rate that causes lack of appreciation of modern information services and their use.

The list may go on and on. Any experienced library manager from a developing country can surely add quite a few more points to the above list. In short, existing libraries in the developing countries are struggling for their mere existence. Of course there are many reasons for the lack of resources for library development. In countries where citizens still struggle for reliable sources of food, water, medical care and educational opportunities, bridging the digital divide may seem like a lofty goal, and that's is why digital library development is way down the list of priorities of governments and institutions.

What is the solution then? Should the library and information professionals sit behind and watch their developed counterparts embrace new technologies and excel in the provision of information services? Should the majority of the world population, who live in the developing and least developed countries, become information poor day by day? Or are there any hopes?

This paper highlights some recent developments in the library and information world that may be quite encouraging for information professionals and users in the developing countries. In fact, over the past few years many new services have appeared that can be used by anyone, anywhere and are free at the point of use. Many of these new services are the consequences of digital library research, while others are the results of new economic models of the information industry, and some are the results of good gestures to help people. The rest of this paper highlights some of these developments, and proposes some measures to be taken by the library and information professionals in the developing countries, or even those in the developed countries, to reap the benefits of the global digital library research and development activities.

\section{New Services and Facilities}

The following sections briefly mention the features of some new services and facilities that can be used by anyone for free. The list is by no means exhaustive, and one can easily find many more such services and facilities. Nevertheless, the following sections show that library and information professionals who do not have access to huge budgets and other resources to venture on digital libraries, can still provide good quality services to their users at almost no additional cost. Of course, the basic IT infrastructure and Internet access are the pre-requisites to these services, but the cost to this is negligible compared to the contents, and, above all, the benefits that the end users may get by availing these services.

\section{Information from Government, Regional and International Organizations}

One of the direct impacts of the Internet on the governments and the regional and international organizations has been that they are now trying to make as much information available on the net as possible. As a result, end users can get access to the up to date (as much as possible) information for which, even a few years ago, they had to wait for long and had to go through a number of hassles. Asian governments are well represented on the web - in most cases detailed information about the government ministries, departments, policies, activities, publications, etc., are available on the web. The e-ASEAN Task Force was created in 1999 by the Association of Southeast Asian Nations (ASEAN) to develop a broad and comprehensive action plan for an ASEAN e-space with an aim to give 
directives to the ASEAN governments for establishing an ASEAN Information Infrastructure (AII) [11].

Regional and international organizations also make useful information about them - organization, activities, publications, etc. - available on the web. In addition, thousands of NGOs (Nongovernmental organizations) have set up their website in order to provide access to a number of useful information resources about government, and various socio-political and economic issues.

Information and library professionals in the developing countries may provide access to all of these, or preferably to selected and the most appropriate, web information resources to their users by creating a simple webpage providing links to the various resources. A better and more useful approach will be to organise the resources into various categories according to their content, sources, and/or the user requirements. Users can easily navigate through such an organised structure of information sources.

\section{Information Through Subject Gateways and Virtual Libraries}

One of the most prominent, and useful especially from the end-user perspectives, outcomes of the recent digital library research has been the development of a number of subject gateways. These gateways select and organise valuable subject-specific information resources available on the web, and let the user access to those resources through a custom-built interface. The following are some examples of subject gateways:

- Art and Architecture: ADAM (http://www.adam.ac.uk)

- General: NOVAGate (http://novagate.nova-university.org), BUBL Link (http://link.bubl.ac.uk/)

- Engineering: EEVL (http://www.eevl.ac.uk/) and EELS (http://eels.lub.lu.se/)

- Business and economics: Biz/ed (http://bized.ac.uk)

- Health and medicine: OMNI (http://www.omni.ac.uk/)

- Social science: SOSIG (http://www.sosig.ac.uk/)

A detailed list of various subject gateways and virtual libraries appears in Chowdhury and Chowdhury [12]. Library and information professionals can make one or more of these subject gateways accessible to their users by pointing to the appropriate service websites from then own webpage. Alternatively, they may point the users to a general subject gateway like BUBL that would allow the user to browse or search the web information resources by subject or discipline.

\section{Digital Reference and Information Services}

A number of reference and information services are now available on the web. Interestingly, many of these services are provided by non-library and commercial organisations. While some of these services are free, others need the users to pay. Detailed discussions on such services are available in a number of recent publications (see for example, [12-15]). McKiernan [16] maintains a site that provides categorised listing of libraries that offer real-time reference services using chat software, live interactive communication tools, call centre management software, bulletin board services and other Internet technologies. Most of these services are designed for registered users of the libraries concerned.

Table 1 provides a quick overview of some online reference and information services that are currently available. This is not an exhaustive list, but the table shows the different types of services that are now available, and also their major characteristics. In addition to those mentioned in Table 1, there are also some web-based reference services where users need to conduct search with a reference query. Such services provide free access to various online reference sources, and allow users to either select a specific source or conduct a search on a range, or all, of the reference sources. Examples of such services include the following:

- Internet Public Library (http://www.ipl.org)

- Infoplease (http://www.infoplease.com) 
- Britannica (http://www.britannica.com)

- Bartleby reference (http://www.bartleby.com/reference)

- Internet Library for Librarians (http://www.itcompany.com/inforetriever/)

- Electric Library (http://ask.elibrary.com/refdesk.asp)

- Mediaeater Reference Desk (http://www.mediaeater.com/easy-access/ref.html)

- ReferenceDesk (http://www.referencedesk.org/)

- Xrefer (http://www.xrefer.com/)

While most of these web-based reference services are available for free, some charge small amount of fees. For example, the Electric Library charges $\$ 79.95$ for an entire year of unlimited access.

Janes, Hill and Rolfe[17] report a study of 20 web-based 'expert services'. By asking 240 questions to 20 selected expert services, they noted that the sites gave verifiable answers to $69 \%$ of factual questions. The high rate of success of factual questions shows that these expert services can be used to find answers to simple (ready reference) type of questions.

While the digital reference and information services are designed specifically for the end-users, library and information professionals may tap on them to provide services to their users. This is particularly true for the developing countries where the end users may not have access to the Internet from their home or office, and where the access is rather expensive. LIS (library and information science) professionals may select one or more web-based reference services according to the nature and need of their users, and either can use those services on behalf of the users or can let the users use on their own.

Table 1: Characteristics of Some Web-based Reference Services

\begin{tabular}{|c|c|c|c|c|c|c|}
\hline Service & Subject & Payment & Organisation & $\begin{array}{l}\text { Service } \\
\text { Providers }\end{array}$ & Question Input & $\begin{array}{l}\text { Mode of } \\
\text { Delivery }\end{array}$ \\
\hline Askme & All & Free & Askme.com & $\begin{array}{l}\text { Experts } \\
\text { (Volunteers } \\
\text { ) }\end{array}$ & $\begin{array}{l}\text { Select a } \\
\text { subcategory and } \\
\text { Input query } \\
\text { through a Web- } \\
\text { based query form }\end{array}$ & e-mail \\
\hline $\begin{array}{l}\text { AllExpert } \\
\mathrm{s}\end{array}$ & All & Free & $\begin{array}{l}\text { Allexperts.co } \\
\mathrm{m}\end{array}$ & $\begin{array}{l}\text { VolunteerE } \\
\text { xperts }\end{array}$ & $\begin{array}{l}\text { Select } \\
\text { subcategory and } \\
\text { enter query } \\
\text { through a Web- } \\
\text { based query form }\end{array}$ & e-mail \\
\hline $\begin{array}{l}\text { LiveAdvi } \\
\text { ce }\end{array}$ & All & $\begin{array}{l}\text { Fee-based } \\
\text { (Each advisor } \\
\text { sets a per- } \\
\text { minute rate } \\
\text { for Phone and } \\
\text { Recorded } \\
\text { Advice } \\
\text { ) }\end{array}$ & $\begin{array}{l}\text { Liveadvice.co } \\
\mathrm{m}\end{array}$ & $\begin{array}{l}\text { Registered } \\
\text { Experts }\end{array}$ & $\begin{array}{l}\text { Select a } \\
\text { subcategory and } \\
\text { enter query } \\
\text { through a Web- } \\
\text { based query form }\end{array}$ & e-mail \\
\hline Find/SVP & Business & $\begin{array}{l}\text { Fee-based } \\
\text { (Users can } \\
\text { choose a cost } \\
\text { band) }\end{array}$ & Findsvp.com & $\begin{array}{l}\text { Business } \\
\text { Experts }\end{array}$ & $\begin{array}{l}\text { Enter query } \\
\text { through a Web- } \\
\text { based query form }\end{array}$ & $\begin{array}{l}\text { e-mail, } \\
\text { phone, } \\
\text { fax, } \\
\text { courier }\end{array}$ \\
\hline $\begin{array}{l}\text { Professio } \\
\text { nal City }\end{array}$ & $\begin{array}{l}\text { Law, } \\
\text { Accounti } \\
\text { ng, } \\
\text { Marketin } \\
\text { g }\end{array}$ & Fee-based & $\begin{array}{l}\text { ProfessionalC } \\
\text { ity.com }\end{array}$ & $\begin{array}{l}\text { LIS } \\
\text { professiona } \\
\text { ls }\end{array}$ & $\begin{array}{l}\text { Enter query } \\
\text { through a Web- } \\
\text { based query form }\end{array}$ & e-mail \\
\hline
\end{tabular}


Access to Electronic Texts - Books, Journals, Theses, etc.

One of the most prominent benefits of digital libraries is that users can get online access to books, journals and other publications such as conference proceedings, theses, etc. Indeed many digital libraries and other services have been set up in the recent past that provide free access to a number of electronic books, journals, theses, etc. The following sections provide some examples free access to ejournals, ebooks, theses, etc.

\section{e-journals}

While most of them are accessible only through payment, some e-journals and books are available for free. Some publishers and associations/organisations are now making journals available free to the readers in some countries. For example

- Blackwells (www.blackwells.co.uk) is making all 600 of its journals freely available to institutions within the Russian Federation [18]

- World Health Organisation (WHO; http://www.who.int) is spearheading an initiative to enable 100 of the world's poorest countries to access 1000 of their top biomedical journals

- Academic Press's Ideal service (www.idealibrary.com) is making 300 science, technology and medicine journals available to research centres across Senegal in west Africa.

- PubMed Central (http://www.pubmedcentral.nih.gov/is) is a digital archive of life sciences journal literature managed by the National Center for Biotechnology Information (NCBI) at the U.S. National Library of Medicine (NLM). It is free for use from anywhere in the world.

A number of free e-journals are now coming up in different subjects. For example, in information science some of the very good and free e-journals include: the D-Lib Magazine, Ariadne, Information Research, and so on. Many such free e-journals are also available in other subjects. One may be sceptical about the qualities of these free e-journals. However, a study by Fosmire and Yu [19] shows that one need not worry about this. They conducted a survey of 1,209 e-journals and noted that 213 $(18 \%)$ of scholarly journals were free. They further noted that these journals have very high impact factors (a measure used to assess the quality of a journal), and each of them has a reasonable numbers of articles published.

\section{E-print Archives and the Open Archives Initiative}

E-prints are seen as a means to fighting the high costs of scholarly publications from publishers. The idea is that the fastest and cheapest way for authors to make their papers available is to store the electronic copies of their papers on e-print servers [20]. Success and rapid growth of arXiv e-print server (http://www.arxiv.org) has given birth to many new e-print services, such as CogPrints (the Cognitive Sciences E-print Archive) (http://cogprints.soton.ac.uk/), front end for the mathematics arXiv (http://front.math.ucdavis.edu/), and WoPeC (Working Papers in Economics) (http://netec.mcc.ac.uk/WoPEc.html). These e-print services can be excellent sources for authentic and up to date research information for users anywhere in the world.

\section{ebooks}

Although electronic books are not yet as common as e-journals, ebook service provided by the netlibrary (http://www.netlibrary.org) is growing very fast. While the netlibrary requires payment for use, many electronic books are now available for free. Some examples are given below:

- The Dictionary.com (http://www.dictionary.com/) site provides access to a number of dictionaries, thesauri, writing resources, and other tools including the automatic webpage translation services

- The eLibrary reference desk (http://ask.elibrary.com/refsearch.asp) provides access to a number of dictionaries, encyclopaedias and almanacs 
- The Classic Book Shop (http://www.classicbookshelf.com/SiteMap.htm) provides access to a number of classic books available in electronic format

- The webbooks.com site (http://www.web-books.com/cool/ebooks/Library.htm) provides access to over 2200 electronic books in different subjects.

\section{Theses, Dissertations, etc.}

The two most prominent digital libraries that provide access to electronic theses, dissertations and scholarly publications are NDLTD (Networked Digital Library of Theses and Dissertations; http://www.NDLTD.org) and NCSTRL (Networked Computer Science Technical Reference Library; http://www.ncstrl.org). These services aim to increase the availability research information to scholars, academics and students. They have grown dramatically over the first few years. NDLTD is now becoming a global access point to electronic theses and dissertations. At the time of writing (May 2002) the site provides access to the theses and dissertations from 138 members - 122 universities from around the world and 16 internationally renowned institutions.

\section{Other Free Digital Libraries}

Many digital libraries provide free access to a variety of digital information resources. The Greenstone Digital Library (GDL; formerly New Zealand Digital Library, NZDL) in New Zealand is a free digital library service that may be particularly valuable for users in the developing countries. Witten et al [21] list five specific areas where digital libraries can promote developments in the developing countries:

1. In the dissemination of humanitarian information

2. in facilitating disaster relief by providing the appropriate information

3. in the preservation and propagation of indigenous culture

4. in building collections of locally-produced information, and

5. in creating new opportunities to enter the global marketplace.

To this we can add another important point that can be applicable to any digital library: digital libraries can facilitate life long learning which is the key to success in this fast changing world.

While discussing the collection and services of the Greenstone Digital Library, and arguing how the digital library can meet many of the above objectives in developing countries, Witten et al. [21] comment that digital libraries provide a golden opportunity to reverse the negative impact of ICT on developing countries.

\section{Summary and Some Action Plans}

While developing countries are threatened by the growing digital divide, and the information professionals and users feel that they are lagging behind the digital library revolution due to the high cost of digital library research and development, as well as due to other factors such as the lack of technology, manpower, and other resources, this paper has shown that many new developments are taking place that may reverse the situation if they are used properly. This paper has pointed out several new services and facilities that are particularly suitable for users in the developing countries. However, the pre-requisite to these services is the availability of basic ICT and Internet facilities. Since this is one of the major problems in the developing world and many users may not have reliable and affordable Internet access from home, or even from work, library and information centres can play a very important role. The following are some simple guidelines that may enable library and information professionals in developing countries make some of the digital library services available to their users without much costs or hassles. The main activities should include:

1. Building and linking local digital libraries: Building digital libraries of local and indigenous materials, is an important step in bridging the digital divide. Many such digital libraries are now being built in the developing countries. Some Asian and African counties, for example Hong Kong, Singapore, Malaysia, India, South Africa, etc., are ahead of others, but other countries are following the suit. A recent example is the development of the Ganesha Digital Library (GDL) Network in Indonesia [22]. 
Many of the projects on building digital libraries of indigenous resources have been initiated and funded by institutions and governments locally, while some have been developed though international collaboration. The Million Books Project, funded by the US National Science Foundation and the governments of China and India is an example of building a digital library of indigenous materials through international collaboration. The project began in 2001 at Carnegie Mellon University, in collaboration with six Chinese universities and ten research centres in India, with an aim to provide full-text searching to one million books, making them accessible to anyone anywhere. The project has received the support of the National Science Foundation (NSF) and the governments of India and China [23].

2. Digital outsourcing: Some free services are mentioned in this paper. However there are many more. Information professionals in the developing countries should spend time on outsourcing of free digital information sources and services. The task of selection should include a number of activities including (a) identification of the appropriate sources and services based on the subject, sources/authority, user requirements, etc. (2) evaluation of the sources in order to assess the suitability of the selected sources and services in the light of the user requirements vis-à-vis the technical requirements to access and use them, and (3) to create some sort of surrogate for each source and service to facilitate organization, etc.

3. Organisation of the digital information sources and services: This may require basic web design skills. Simple web design skills may be acquired easily, and a number of free courses and guides for web design are available on the web. In the absence of anything else, the editor that come with the web browsers (Netscape Navigator, or Internet Explorer) may be used to design simple web pages. The major professional skills will be required in the organisation of the identified digital resources and services. An understanding of the users and their information needs vis-à-vis the content, format, etc., of the selected sources and services may help the information professionals organise them properly. Appropriate tools used for information organisation in traditional libraries (classification schemes, thesauri, etc.) may be used for the purpose.

4. Using Freely available digital library software and support: Free software and support are available from a number of international digital library research groups, such as NDLTD, GDL, etc., which may be used for building local digital libraries.

5. Improving information use: Information use rather than access is a major problem in many developing countries. Paul (2002) comments that 'a major issue in debating the digital divide in ASEAN countries centres more on usage than on wired access or computer ownership.' There are many reasons for poor information usage despite having good access. One of the major reasons is poor information literacy (discussed below). The other most important reason is the work culture and habits. In many countries, more so in the developing world, the work culture does not allow people to spend more time on the Internet, and the day-to-day activities are based more on the traditional approach through the use of paper documents and telephone or written communications.

6. Improving information and digital literacy skills: Poor information and digital literacy is a major problem in the developing countries. Widharto [24] while discussing the problems facing information services in Indonesia comments that training remains a key to the future of the Indonesian libraries. This statement can be generalised for other developing countries too. Information or digital literacy training may be organised at different levels. Because of the limitation of resources, information professionals may begin with a simple approach of providing training to the users at different levels - basic, advanced, etc. Nevertheless, to keep pace with the rapid changes in ICT and digital library systems and services, such training should be provided on a regular basis in order to help the users keep up to date and thereby make the optimum use of the sources and services made available to them.

Digital divide is not only a problem of the developing countries; within the developed countries there are significant proportion of the population for whom the digital divide is as prominent as it is between the north and the south [25]. Nevertheless, as Ross Shimmon [25,26], the Secretary General of IFLA, comments, and this paper has justified, library and information professionals, even with their limited resources, can play a significant role to bridge the digital divide. 
While library and information professionals in a less fortunate situation can play a great role in making use of the recent digital library developments to the benefit of their users, there are some deeper issues too. The digital divide can only be reduced when the users actually make use of the information for the purpose of making informed decisions, and in every aspect of their daily lives. Paul [27] comments that the digital divide can be bridged by improved:

- $\quad$ access, measured by access indicators

- $\quad$ usage, measured by usage indicators, and

- $\quad$ outcome, measured by impact indicators.

Nevertheless, these are difficult parameters to measure, and painstaking research is needed to develop the measuring yardsticks and best practice standards.

\section{References}

1. Cullen, R.: Addressing the digital divide. Online Information Review. 25(2001) 311-320.

2. Digital Divide Basics $\quad$ Fact (http://www.digitaldividenetwork.org/content/stories/index.cfm?key=168)

3. Cronin, B.: The digital divide. Library Journal. 127(2002). 148.

4. Digital Divide Network. http://www.digitaldividenetwork.org

5. Information Rich Information Poor (1999). BBC News. Oct. 14, 1999. http://news.bbc.co.uk/hi/english/special_report/1999/10/99/information_rich_information_poo $\underline{\text { r/newsid } 466000 / 466651 . s t m}$

6. Conhaim,W. W.: The global digital divide. Information Today. 18(2001), http://proquest.umi.com

7. Chowdhury, G.G. and Chowdhury, S.: Introduction to digital libraries. Facet Publishing, London (2002).

8. Rusbridge, C.: After eLib. Ariadne, Issue 26 (2001) http://www.ariadne.ac.uk /issue26/chris/intro.htm

9. Harvard University Library. Digital Library Initiative. http://hul.harvard.edu/ldi/html/costs

10. About UCEEL. http://diglib.uce.ac.uk/webgate/dlib/templates/about.asp

11. e-Task Force. http://www.e-aseantf.org/

12. Chowdhury, G.G. and Chowdhury, S.: Information sources and searching on the world wide web. Library Association Publishing, London (2001).

13. Chowdhury, G.G.: Digital libraries and reference services: present and future. Journal of Documentation. 58(2002), 258-283.

14. Lankes, D., Collins, J.W. \& Kasowitz, A.S. (eds): Digital reference service in the new millennium: planning, management, and evaluation, Neal-Schuman (2000)

15. Sherman, C.: Reference resources on the Web. Online, 24(2000), 52-56. 
16. McKiernan, G.: LiveRef(Sm): a registry of real-time digital reference services. http://www.public.iastate.edu/ CYBERSTACKS/LiveRef.htm

17. Janes, J; Hill, C., Rolfe, A.: Ask-an-expert services analysis. Journal of the American Society for Information Science and Technology. 52 (2001), 1106-21.

18. Smith, G. Closing the digital divide. Information World Review. (2001). Online. Downloaded from http://proquest.umi.com

19. Fosmire., M. and Yu, Song: Free Scholarly Electronic Journals: How Good Are They? Issues in Science and Technology Librarianship, Summer 2000. Online: http://www.library.ucsb.edu/istl/00-summer/refereed.html

20. Day, M.: E-print Services and Long-term Access to the Record of Scholarly and Scientific Research. Ariadne. Issue 28 (2001). http://www.ariadne.ac.uk /issue28/metadata/intro.html

21. Witten, I. H., Loots, M., Trujillo, M.F., and Bainbridge, D. : The promise of digital libraries in developing countries. The Electronic Library. 20(2002), 7-13.

22. Fahmi, I.: The Indonesian Digital Library Network is born to struggle with Digital Divide. Bulletin of the American Society for Information Science. 28(2002), 19-24.

23. Michalek., G.: The Universal Library and the Million Book Project. D-Lib Magazine. 8(2002), http://www.dlib.org/dlib/june02/06inbrief.html\#MICHALEK

24. Widharto: Challenges in accessing scientific and technological information in Indonesia during the economic crisis. Bulletin of the American Society for Information Science and Technology. 28(2002), 25-27.

25. Shimmon, R.: From digital divide to digital opportunity. (2001). Online. http://www.unesco.org/webworld/points_of_view/shimmon.html

26. Shimmon, R. Can we bridge the digital divide? Library Association Record. 103(2001), 678679.

27. Paul, J. : Narrowing the digital divide: initiatives undertaken by the Association of South-East Asian Nations (ASEAN). Program, 36(2002), 13-22 